\title{
改进多目的地旅行公共费用分成模型及其在 若尔盖县游熄价值评估中的应用
}

\author{
邓惁涛 ${ }^{1}$, 尚 闽 $^{1}$,杨志娟 ${ }^{1}$,杨 渺 $^{2}$,杨正兴 ${ }^{1}$,何斯妙 ${ }^{1}$ \\ (1. 四川省阿坝生态环境监测中心站, 阿坝 624000; 2. 四川省生态环境科学研究院, 成都 610041)
}

\begin{abstract}
摘要: 多目的地环程旅行问题是应用旅行费用法 (TCM) 进行游㮩价值评估的难点和热点, 客观 准确地对多目的地旅行公共费用进行分成, 确定各目的地的费用权重成为游鄎价值评估的关 键性问题。因此, 本文引人旅行公共费用和目的地直接费用的概念, 改进多目的地旅行公共费 用分成计算模型, 将待评估目的地直接费用与多目的地总直接费用的比值作为待评估目的地 在旅行公共费用中的分成权重。该计算模型尝试根据调查游客自身的消费特点进行旅行公共 费用分成, 避免主观假设的影响, 旨在使费用分成更加客观、科学。对若尔盖县游㮩价值的评 估结果为: 2017 年若尔盖县游㰾价值为 31.09 亿元, 人均游惒价值 1538 元; 其中旅行费用 25.06 亿元, 人均旅行费用 1240 元; 消费者剩余 6.03 亿元, 人均消费者剩余 298 元。通过改进多 目的地旅行费用分成模型, 可推动游憩价值评估方法的发展和完善。研究结果可为若尔盖县 生态旅游产业发展规划提供科学指导。
\end{abstract}

关键词: 游䪹价值;旅行费用法;多目的地旅行;费用分成模型;若尔盖县

游頽价值作为生态价值评估的重要组成部分, 客观准确的评估结果有利于指导当地 旅游产业布局发展, 还能为政府管理和决策提供科学依据 ${ }^{[1]}$ 。旅行费用法（Travel Cost Method，TCM）是评估游䕀价值的经典方法，通过消费者剩余和实际旅行费用相加计算 得到游憩资源价值, 被众多学者应用并得到发展 ${ }^{[2]}$ 。TCM 方法在理论和实践上都已相对 成熟, 但对于广为存在的多目的地环程旅行问题, 特别是长假旅行, 目前还没有好的方 法将其纳人传统的基本模型[3]。多目的地旅行问题能否得到客观准确的处理, 将对旅行费 用计算结果有显著的影响, 从而影响旅游消费者剩余 ${ }^{[4]}$ 。因此, 改进多目的地旅行费用计 算方法或模型也成为 TCM 研究应用中的难点和热点问题 ${ }^{[5]}$ 。

我国进行游悡价值评估和研究起步较晚，早期多目的地问题一般都被研究者忽略不 计, 即便有所考虑, 也多采用简单平分的办法 ${ }^{[5,6]}$ 。多目的地旅行费用的计算方法主要有 景点组合 ${ }^{[7]}$ 、游客偏好 ${ }^{[8]}$ 和费用分成 ${ }^{[9]}$ 等。景点组合实际操作难度较大, 很难准确了解到 游客的多个目的地, 根据经验假设的可能目的地, 并不能全面反映实际情况。有研究表 明要游客清楚地表达对各目的地偏好是很困难的 ${ }^{[10]}$, 因此以游客偏好进行多目的地旅行 费用的计算具有较大的局限性。况且该方法属于 “自述偏好” 类型, 偏离了 TCM “显示

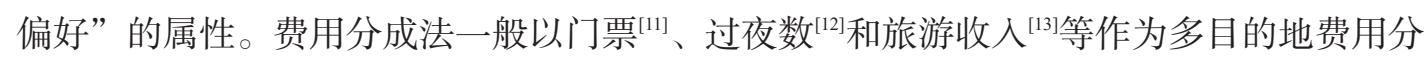

收稿日期：2019-04-11; 修订日期：2019-09-02

基金项目：四川省科技计划重点研发项目（2017SZYZF0007）

作者简介: 邓惁涛（1974- ), 男, 四川阿坝人, 高级工程师, 研究方向为环境管理、生态补偿政策制定。 E-mail: 2453000472@qq.com

通讯作者：尚闽（1988-), 男, 四川成都人，硕士，工程师，研究方向为资源环境、生态系统价值评估。 E-mail: shangmin@ruc.edu.cn 
成的权重指标，因其可操作性强而成为被广泛应用的多目的地旅行费用分成计算方法 ${ }^{[0]}$ 。 但费用分成所选用的权重指标只是间接反映多目的地的相对重要性和游客吸引力 ${ }^{[14]}$, 不 能直接反映被调查游客对多目的地的真实喜好，具有一定的局限性。

若尔盖湿地是世界最大的高原泥炭沼泽湿地及高寒湿地生态系统的典型代表，准确 评估湿地生态系服务价值是进行湿地生态效益评价和旅游资源管理的重要依据 ${ }^{[15]}$ 。若尔 盖县是若尔盖湿地的重要组成区域，境内建有的若尔盖湿地国家级自然保护区和若尔盖 国家湿地公园是湿地保护的主要形式 ${ }^{[16]}$ 。同时若尔盖县是川甘青三省交界、远离中心城 市的民族地区，具有独特的高寒湿地自然景观和民族风俗旅游资源，境内有黄河九曲第 一湾、热尔大草原、花湖等多个著名旅游景区。评估若尔盖县游憩价值对当地旅游资源 管理具有重要意义。

因此, 本文以若尔盖县为研究对象, 选取游客最为集中的若尔盖花湖和九曲黄河第 一湾两个景区为样本点, 基于区间旅行费用法, 针对多目的地旅行费用的计算问题, 对 费用分成计算模型进行改进。把总旅行费用分为旅行公共费用和多目的地总直接费用， 将评估目的地直接费用与多目的地总直接费用的比值作为评估目的地在旅行公共费用中 的分成权重，依据被调查游客自身的消费特点进行旅行公共费用分成，直接显示被调查 游客对目的地的偏好, 旨在使费用分成更加客观、科学合理, 进而推动游慗价值评估方 法的理论创新。应用改进费用分成计算模型对若尔盖县游㮩价值进行评估，对高寒湿地 和民族地区游㰾价值评估具有重要的科学实践指导意义。

\section{1 研究方法与数据来源}

\section{1 研究区概况}

若尔盖县地处青藏高原东北边缘，位于 $102^{\circ} 08^{\prime} \sim 103^{\circ} 39^{\prime} \mathrm{E} 、 32^{\circ} 56^{\prime} \sim 34^{\circ} 19^{\prime} \mathrm{N}$ 之间，全 县面积 $10204 \mathrm{~km}^{2}$, 隶属阿坝藏族羌族自治州, 位于四川省西北部。若尔盖县属高原寒带 湿润季风气候, 多年平均降雨量 $656.8 \mathrm{~mm}$, 集中在 4-9月。境内有大小河流 20 余条, 分 属黄河水系和长江水系, 县内有高原沼泽湿地面积约 $4500 \mathrm{~km}^{2}$ 。若尔盖县是国家一级保 护动物 “黑颈鹤” 的故乡, 是中国三大名马 “河曲马” 的原产地, 也是世界唯一野生种 群一一四川铁布梅花鹿的家园。据阿坝州文化体育和旅游局统计数据：2007年若尔盖县 旅游人次达到 50.18 万人次， 2008 年受汶川 “ $5 \cdot 12$ ” 地震影响，旅游人次降到 10.98 万 人次, 此后每年保持 15 万 40 万人次的增长速度，到 2016 年旅游人次达到 218.99 万，旅 游业逐渐成为当地支柱产业。2017年受九寨沟 “ 8 - 8 ” 地震影响，旅游人次有所下降， 为 202.19 万。

\section{2 问卷调查}

问卷调研小组于 2018 年 8 月 8 日至 11 日期间在游客最为集中的花湖和九曲黄河第一 湾两个主要旅游点进行抽样调查。共发放问卷 375 份，收回问卷 368 份，其中有效问卷 343 份，有效回收率 $91.47 \%$ 。此次调查问卷设计的主要信息包括旅行总费用、旅行交通 费用、若尔盖县食宿、门票、旅游纪念品、娱乐活动等费用, 以及旅行天数、游客月收 人、来若尔盖旅行次数等。问卷采取随机访问式填写，被采访人填写后现场收回。

在调查样本中, 男性游客比例占 $51.3 \%$, 女性游客比例为 $48.7 \%$, 游客性别比例基本 均衡; 其中自由行游客数量占样本量的 $61.8 \%$, 跟团游游客占 $38.2 \% ; 77.4 \%$ 的问卷调查 
游客表示愿意再来若尔盖旅游， $22.6 \%$ 的游客表示不会再来。游客地域分布主要集中在四 川以及邻近若尔盖县的陕西、甘肃、重庆四个省市, 占到游客总数的 $3 / 4$ 左右; 游客月收 人分布主要集中在 $<1500$ 元、3001 5000 元、5001 8000 元三个收人段，其中月收人 $<1500$ 元的游客主要是学生，月收人 $>8000$ 元的游客占 $19 \%$; 年龄分布主要集中在 $16 \sim$ 45 岁, 占到游客总数的 $72 \%$, 年龄 $>60$ 岁的游客只占 $2 \%$, 年龄 $<15$ 岁的游客占 $11 \%$; 文化程度主要集中在大专和本科阶段，共占游客总数的 $64 \%$, 高中和高中以下文化游客 占 $28 \%$ ，其中 15 岁以下学生占 $11 \%$ 。（图 1)。

\section{3 改进费用分成模型}

旅行费用法经过长期应用和发展，目前主要方法有分区旅行费用法（Zonal Travel Cost Method，ZTCM）、一般个人旅行费用法（Individual Travel Cost Method，ITCM）、 高级个人旅行费用法（Advanced Individual Travel Cost Method，AITCM）、旅行费用区间 分析法（Travel Cost Interval Analysis，TCIA）。有研究表明对于游客重游率低、路途遥远 景区（如九寨沟和若尔盖）游憩价值的计算, TCIA与 ITCM、AITCM 和ZTCM 相比较有 一定的优越性 ${ }^{[17,18]}$ 。因此，本文选用旅行费用区间分析法对若尔盖县游憩价值进行评估。

在应用 TCIA 法进行游憩价值评估时，多目的地旅行中待评估目的地旅行费用 (TC) 的计算非常关键。本文将旅行费用分为旅行公共费用和目的地直接费用。旅行公

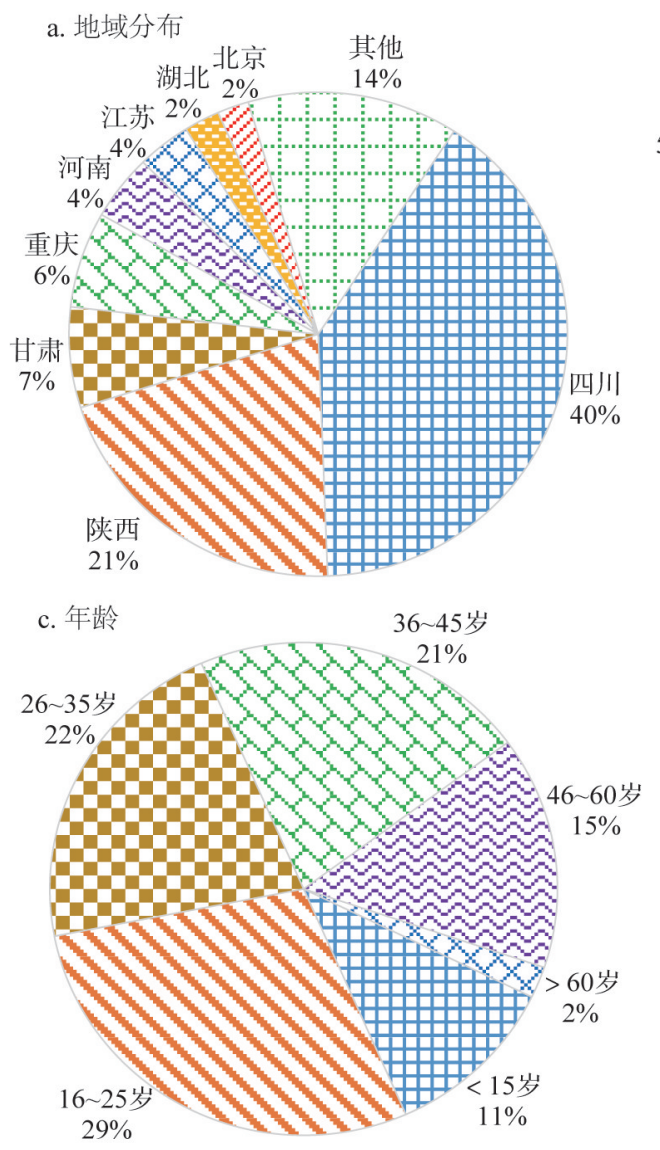

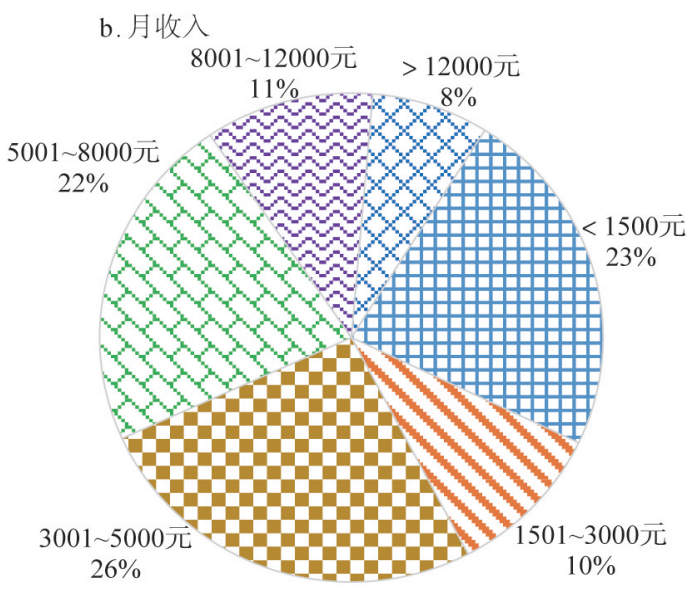

d. 文化程度 研究生及以上 高中以下

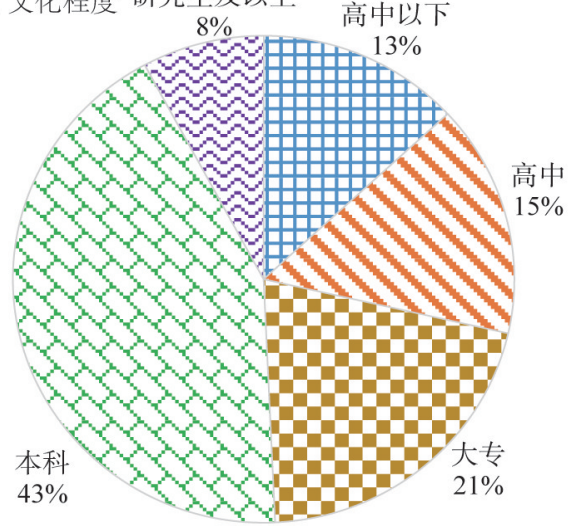

图 1 游客地域、月收人、年龄、文化程度分布示意图

Fig.1 The distribution of tourists' region, monthly income, age and education level 
共费用包括旅行交通、途中食宿和旅行时间成本等费用，目的地直接费用包括在目的地 的门票、食宿、购物娱乐活动等费用。通过问卷调查分析计算, 获得多目的地游客的总 旅行费用、旅行公共费用、多目的地总直接费用和待评估目的地直接费用，其中多目的 地总直接费用等于总旅行费用与旅行公共费用之差。待评估目的地的旅行费用等于待评 估目的地直接费用与公共费用分成之和。针对公共费用分成难的问题，本文尝试改进费 用分成模型，将待评估目的地直接费用与多目的地总直接费用的比值作为待评估目的地 在旅行公共费用中的分成权重，以此分成权重确定待评估目的地占公共费用的比例和大 小。评估目的地旅行费用、公共费用分成权重和旅行公共费用的计算公式分别为:

$$
\begin{gathered}
T C=T_{1}+T_{2} \times K \\
K=\frac{T_{1}}{T_{4}}=\frac{T_{1}}{T_{3}-T_{2}} \\
T_{2}=T_{5}+T_{6}=T_{5}+\frac{D \times Y}{90}
\end{gathered}
$$

式中: $T C$ 为评估目的地旅行费用 (元); $T_{1}$ 为评估目的地直接费用 $\left(\right.$ 元) $; T_{2}$ 为旅行公共 费用 (元); $K$ 为评估目的地公共费用分成权重; $T_{3}$ 为总旅行费用 (元); $T_{4}$ 为多目的地总 直接费用 $($ 元 $) ; T_{5}$ 为旅行途中交通和食宿费用 (元); $T_{6}$ 为旅行时间机会成本费用 (元); $D$ 为此次旅行天数 (天); $Y$ 为游客个人月收人 (元)。

\section{2 结果分析}

\section{1 旅行费用计算}

根据问卷调查获取的样本数据信息, 结合多目的地旅行公共费用分成模型, 计算得 到每一个样本游客到若尔盖县的旅行费用。游客样本集合总的旅行费用计算公式为：

$$
S T C=\sum_{i=1}^{n} T C_{i}
$$

式中: $S T C$ 为游客样本集合总的旅行费用 (元); $T C_{i}$ 为第 $i$ 个样本游客到若尔盖县的旅行 费用 (元); $n$ 为样本数 (个)。

将 343 个样本游客旅行费用加和，得到游客样本集合总的旅行费用为 425194 元，游客 到若尔盖县的平均旅行费用为 1240 元，其中平均直接费用为 752 元，平均分成交通和食宿 费用为 328 元，平均分推时间成本为 180 元。结合阿坝州文化体育和旅游局提供的 2017 年 若尔盖县旅游人次为 202.19 万的数据，计算得到 2017 年若尔盖县旅行费用为 25.06 亿元。

\section{2 消费者剩余计算}

根据问卷调查数据，应用改进的旅行费用分成计算模型，对每一个样本游客到若尔 盖县的旅行费用进行计算。然后采用 TCIA 法对旅行费用进行区间处理（表 1）。运用 SPSS 19.0 软件中的 Curve Estimation 11 个函数功能对每个区间的单个游客到若尔盖县的 意愿旅游需求进行回归分析, 结果表明: 指数、复合增长曲线模型拟合一致, 且拟合最 好。因此, 若尔盖县的旅游总需求函数可以表述为式 (5) 的指数增长形式, 积分计算各 区间单个游客的消费者剩余 [式（6）] 和游客样本集合的总消费者剩余公式 ${ }^{[18]}$ 分别如下:

$$
\begin{gathered}
Q(C)=2.762 \mathrm{e}^{-0.0017 C}, R^{2}=0.9349 \\
C S_{i}=\int_{C_{i}}^{\infty} Q(C) \mathrm{d} C=2.762 \int_{C_{i}}^{\infty} \mathrm{e}^{-0.0017 C} \mathrm{~d} C
\end{gathered}
$$


表 1 样本按旅行费用分段结果

Table 1 The results of sample segmentation by travel cost

\begin{tabular}{|c|c|c|c|c|c|c|}
\hline$i$ & {$\left[C_{i}, C_{i+1}\right]$} & $N_{i} /$ 个 & $M_{i} /$ 个 & $P_{i} / \%$ & $Q_{i} / \%$ & $C S_{i} /$ 元 \\
\hline 1 & $0 \sim 499$ & 5 & 343 & 100 & 1.00 & 1625 \\
\hline 2 & $500 \sim 599$ & 15 & 338 & 99 & 0.99 & 694 \\
\hline 3 & $600 \sim 699$ & 20 & 323 & 94 & 0.94 & 586 \\
\hline 4 & $700 \sim 799$ & 26 & 303 & 88 & 0.88 & 494 \\
\hline 5 & $800 \sim 899$ & 27 & 277 & 81 & 0.81 & 417 \\
\hline 6 & $900 \sim 999$ & 28 & 250 & 73 & 0.73 & 352 \\
\hline 7 & $1000 \sim 1099$ & 38 & 222 & 65 & 0.65 & 297 \\
\hline 8 & $1100 \sim 1199$ & 29 & 184 & 54 & 0.54 & 250 \\
\hline 9 & $1200 \sim 1299$ & 28 & 155 & 45 & 0.45 & 211 \\
\hline 10 & $1300 \sim 1399$ & 24 & 127 & 37 & 0.37 & 178 \\
\hline 11 & $1400 \sim 1499$ & 19 & 103 & 30 & 0.30 & 150 \\
\hline 12 & $1500 \sim 1599$ & 11 & 84 & 24 & 0.24 & 127 \\
\hline 13 & $1600 \sim 1699$ & 12 & 73 & 21 & 0.21 & 107 \\
\hline 14 & $1700 \sim 1799$ & 13 & 61 & 18 & 0.18 & 90 \\
\hline 15 & $1800 \sim 1899$ & 14 & 48 & 14 & 0.14 & 76 \\
\hline 16 & $1900 \sim 1999$ & 8 & 34 & 10 & 0.10 & 64 \\
\hline 17 & $2000 \sim 2499$ & 15 & 26 & 8 & 0.08 & 54 \\
\hline 18 & $2500 \sim 2999$ & 8 & 11 & 3 & 0.03 & 23 \\
\hline 19 & $\geqslant 3000$ & 3 & 3 & 1 & 0.01 & 10 \\
\hline
\end{tabular}

注： $\left[C_{i}, C_{i+1}\right]$ 为旅行费用的分段区间; $N_{i}$ 为区间 $\left[C_{i}, C_{i+1}\right]$ 内的游客人数; $M_{i}$ 为旅行费用为 $C_{i}$ 时样本游客的旅游需 求量; $P_{i}$ 为旅行费用为 $C_{i}$ 时游客的出游的概率, 百分比表示; $Q_{i}$ 为旅行费用为 $C_{i}$ 时单个游客的需求率; $C S_{i}$ 为旅行费 用为 $C_{i}$ 时单个游客的消费者剩余。

$$
S C S=\sum_{i=1}^{n} N_{i} \times C S_{i}
$$

式中： $C S_{i}$ 为第 $i$ 个区间每个游客的消费者剩余（元）， $C_{i}$ 为第 $i$ 个区间旅行费用的左端点 (即区间下限); $Q(C)$ 为单个游客的意愿旅游需求曲线; $S C S$ 为总消费者剩余 (元); $n$ 为 区间个数 (个); $N_{i}$ 为第 $i$ 个区间的游客数量 (个)。

依式（6）得每一区间段单个游客的消费者剩余（表1）。依式（7）得到游客样本集 合总的消费者剩余为 102271 元，平均单个游客到若尔盖县的消费者剩余为 298 元。

\section{3 游憩价值计算}

若尔盖县的总游憩价值（Recreation Value，RV）等于若尔盖县游客总的旅行费用和 总的消费者剩余价值之和，计算公式 ${ }^{[18]}$ 为：

$$
R V=(S C S+S T C) \times \frac{T N}{S N}
$$

式中: $R V$ 为若尔盖县游憩价值 (元); $S N$ 为样本游客数 (个); $T N$ 为 2017 年若尔盖县旅 游人次 (个)。

已知 2017 年若尔盖县旅游人次为 202.19 万，游客样本集合总的旅行费用为 425194 元， 游客样本集合总的消费者剩余为 102271 元，样本数量有 343 个; 根据式（8）计算得到 2017 年若尔盖县生态系统游憩价值为 31.09 亿元，游客人均游憩价值为 1538 元。 


\section{3 结论与讨论}

通过引人旅行公共费用和目的地直接费用两个概念，对多目的地旅行公共费用分成 计算模型进行改进，并以四川若尔盖县为例评估其 2017 年的游㮩价值。结果表明: 2017 年若尔盖县的游憩价值为 31.09 亿元，其中旅行费用 25.06 亿元，消费者剩余 6.03 亿元； 2017 年若尔盖县人均游憩价值 1538 元，其中人均旅行费用 1240 元，人均消费 者剩余 298 元。研究结果可为若尔盖县生态旅游产业发展规划提供科学指导。

本文研究得到的若尔盖县人均游憩价值与他人研究得到的九寨沟景区和若尔盖县的 人均游慜价值进行比较（表 2 ，按当前存款利率 $1.95 \%$ 换算成 2017 年的净现值。按照若尔 盖县和红原县的游客比例对张晓云等 ${ }^{\left[{ }^{[9]}\right.} 13.44$ 亿元的评估结果进行分配计算，得到若尔盖 县的游憩价值为 6.34 亿元), 若尔盖县人均游憩价值低于九寨沟景区。本文的 2017 年若 尔盖县游客人均目的地直接费用 752 元与阿坝州文化体育和旅游局统计数据若尔盖县人 均旅行费用 668 元基本一致，表明本文评估结果比较符合客观事实。张晓云等 ${ }^{\left[{ }^{19]}\right.}$ 和庞丙亮 等 ${ }^{[20]}$ 对若尔盖县的人均游㮩价值评估结果高于本文和九寨沟景 ${ }^{[5,11,17]}$ ，这与选用不同的 旅行费用法和旅行费用分成计算模型有关，人均游㮩价值评估结果相差较大。不断改进 和完善评估方法，在一定范围内分类别建立标准化的评估方法，有利于实现不同地区和 不同类型景区游憩价值的可比性，反过来对比分析结果可促进方法的不断完善和规范。

\section{表 2 若尔盖县和九寨沟景区游䕀价值评估结果}

Table 2 The evaluation results of recreation value in Zoige county and Jiuzhaigou valley

\begin{tabular}{|c|c|c|c|c|c|c|}
\hline 数据来源 & 数据年份 & 评估对象 & 总价值/亿元 & 游客量/万人次 & 人均值/元 & 2017年净现值/元 \\
\hline 李巍等 ${ }^{[17]}$ & 2000 & 九寨沟景区 & 10.85 & 82.00 & 1323 & 1837 \\
\hline 张茵等 ${ }^{[5]}$ & 2002 & 九寨沟景区 & 15.61 & 125.30 & 1246 & 1665 \\
\hline 张晓云等 ${ }^{[19]}$ & 2006 & 若尔盖县 & 6.34 & 40.00 & 1585 & 1960 \\
\hline 董雪旺等 ${ }^{[1]}$ & 2009 & 九寨沟景区 & 48.90 & 252.18 & 1939 & 2263 \\
\hline 庞丙亮等 ${ }^{[20]}$ & 2011 & 若尔盖县 & 24.40 & 81.76 & 2984 & 3351 \\
\hline 本文 & 2017 & 若尔盖县 & 31.09 & 202.19 & 1434 & 1538 \\
\hline
\end{tabular}

用旅行费用法进行游憩价值评估时，目前多目的地旅行费用分配处理方法有：（1）把 多目的地旅行样本当单目的地样本或剔除;（2）把单、多目的地旅行分别代人模型计算; (3) 将总旅行费用按比例分成。以上方法都存在主观随意性问题, 按比例分成是相对较 好的一种方法，且评估目的地组合情况及如何确定其在旅行费用中的占比是费用分成法 亟待解决的关键问题 ${ }^{[14]}$ 。但费用分成所选用的比例指标，如旅游资源等级、过夜数、旅 游收人、门票价格、游客满意度等 “显示偏好” 数据，只间接反映多目的地相对重要性

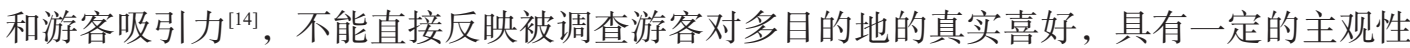
和局限性。如何将旅行费用在多目的地之间进行合理分推依然是难以解决的问题。

因此，本文引人旅行公共费用和目的地直接费用概念，目的地直接费用通过抽样调 查游客在目的地的门票、食宿、购物娱乐活动等费用直接获得，不存在费用分成的问 题; 因此，仅需对旅行公共费用进行分成计算，降低了费用分成带来的偏差风险。针对 旅行公共费用分成的问题，本文尝试建立新的旅行费用分成模型，以调查目的地直接费 用与多目的地总直接费用的比值作为调查目的地在旅行公共费用中的分成权重，不需要 对其他目的地进行调查，仅根据评估目的地游客消费情况进行费用分成，不仅减少了评 
估工作量, 还有效避免了主观因素的干扰影响。但本文建立的多目的地旅行公共费用分 成模型也存在一定不足，例如，如何区分旅途中的交通食宿费用和目的地的交通食宿费 用，即公共费用如何准确界定等问题。因此，需要进一步同其他方法模型进行对比验证 分析，不断改进完善，有望在游憩价值评估中得到广泛应用和发展。

\section{参考文献(References):}

[1] 谢高地, 张彩霞, 张雷明, 等. 基于单位面积价值当量因子的生态系统服务价值化方法改进. 自然资源学报, 2015, 30 (8): 1243-1254. [XIE G D, ZHANG C X, ZHANG L M, et al. Improvement of the evaluation method for ecosystem service value based on per unit area. Journal of Natural Resources, 2015, 30(8): 1243-1254.]

[2] 赵剑波, 杨雪丰, 杨雪梅, 等. 基于旅行费用法的拉萨市主要旅游点游憩价值评估. 干旱区资源与环境, 2017, 31(8): 203-208. [ZHAO J B, YANG X F, YANG X M, et al. Recreational value assessment on the main tourist attractions of Lhasa based on travel cost. Journal of Arid Land Resources and Environment, 2017, 31(8): 203-208.]

[3] PARSONS G R. The travel cost method. In: CHAMP P A, BOYLE K J, BROWN T C. Primer on Non-maket Valuation. London: Kluwer Academic Publishing, 2003: 269-329.

[4] 查爱苹, 邱洁威, 姜红. 旅行费用法若干问题研究. 旅游学刊, 2010, 25(1): 32-37. [ZHA A P, QIU J W, JIANG H. Study on several issues of travel cost method. Tourism Tribune, 2010, 25(1): 32-37.]

[5] 张茵, 蔡运龙. 基于分区的多目的地 TCM 模型及其在游㕰资源价值评估中的应用: 以九寨沟自然保护区为例. 自然 资源学报, 2004, 19(5): 651-661. [ZHANG Y, CAI Y L. Using a multiple-destination-based zonal travel cost method to evaluate the recreational benefits of Jiuzhaigou Nature Reserve. Journal of Natural Resources, 2004, 19(5): 651-661.]

[6] 赵玲, 王尔大, 苗翠翠. ITCM 在我国游咊价值评估中的应用及改进. 旅游学刊, 2009, 24(3): 63-69. [ZHAO L, WANG E D, MIAO C C. On the application of ITCM in the evaluation of China's recreational value and its improvement. Tourism Tribune, 2009, 24(3): 63-69.]

[7] 郑芳, 侯迎, 王乃昂, 等. 多目的地 ZTCM 在旅游价值评估中的应用: 以嘉峪关市为例. 人文地理, 2009, 24(1): 123128. [ZHENG F, HOU Y, WANG N A, et al. The application of multi-destination ZTCM to evaluating the recreational values of tourism resources: A case study of Jiayuguan city. Human Geography, 2009, 24(1): 123-128.]

[8] CHAUDHRY P, TEWARI V P. A comparison between TCM and CVM in assessing the recreational use value of urban forestry. International Forestry Review, 2006, 8(4): 439-448.

[9] 许丽忠, 张江山, 王菲凤, 等. 熵权多目的地 TCM 模型及其在游憩资源旅游价值评估中的应用: 以武夷山景区为例. 自然资源学报, 2007, 22(1): 28-36. [XU L Z, ZHANG J S, WANG F F, et al. Principles and application of using entropyweight- based multiple- destination Travel Cost Method to evaluate the tourism value of recreation resources: A case study of Wuyishan. Journal of Natural Resources, 2007, 22(1): 28-36.]

[10] HAIKOWICZ S A, MCDONALD G T, SMITH P N. An evaluation of multiple objective decision support weighting techniques in natural resource management. Journal of Environmental Planning and Management, 2000, 43(4): 505-518.

[11] 董雪旺, 张捷, 蔡永寿, 等. 基于旅行费用法的九寨沟旅游资源游憩价值评估. 地域研究与开发, 2012, 31(5): 78-84. [DONGX W, ZHANG J, CAI Y S, et al. Measuring the recreational value of Jiuzhaigou World Heritage Site based on travel cost method. Areal Research and Development, 2012, 31(5): 78-84.]

[12] 郭剑英, 王乃昂. 旅游资源的旅游价值评估: 以敦煌为例. 自然资源学报, 2004, 19(6): 811-817. [GUO J Y, WANG N A. Assessing the tourism value of tourism resources: A case study of Dunhuang. Journal of Natural Resources, 2004,19 (6): 811-817.]

[13] 郭剑英. 乐山大佛旅游资源的国内旅游价值评估. 地域研究与开发, 2007, 26(6): 104-107. [GUO J Y. Assessing the tourism value of tourism resources of Leshan Grand Buddha. Areal Research and Development, 2007, 26(6): 104-107.]

[14] 董雪旺, 张捷, 章锦河, 等. 旅行费用法在旅游资源价值评估中的若干问题述评. 自然资源学报, 2011, 26(11): 19831993. [DONG X W, ZHANG J, ZHANG J H, et al. Review on several issues of travel cost method in tourist resources valuation. Journal of Natural Resources, 2011, 26(11): 1983-1993.]

[15] 张彪, 史芸婷, 李庆旭, 等. 北京湿地生态系统重要服务功能及其价值评估. 自然资源学报, 2017, 32(8): 1311-1324. [ZHANG B, SHI Y T, LI Q X, et al. The key ecological services and their values of wetland ecosystems in Beijing. Journal of Natural Resources, 2017, 32(8): 1311-1324.]

[16] 周婷, 牛安逸, 马姣娇, 等. 国家湿地公园时空格局特征. 自然资源学报, 2019, 34(1): 26-39. [ZHOU T, NIU A Y, MA J J, et al. Spatio-temporal pattern of national wetland parks. Journal of Natural Resources, 2019, 34(1): 26-39.]

[17] 李巍, 李文军. 用改进的旅行费用法评估九寨沟的游憩价值. 北京大学学报: 自然科学版, 2003, 39(4): 548-555. [LI 
W, LI W J. Using a modified travel cost method to evaluate the recreational benefits of Jiuzhaigou Nature Reserve. Acta Scicentiarum Naturalum Universitis Pekinesis, 2003, 39(4): 548-555.]

[18] 谢双玉, 些瑞昭, 许英杰, 等. 旅行费用区间分析法与分区旅行费用法的比较及应用. 旅游学刊, 2008, 23(2): 41-45.

[XIE S Y, ZI R Z, XU Y J, et al. A comparison between travel cost interval analysis method and zonal travel cost method and its application. Tourism Tribune, 2008, 23(2): 41-45.]

[19] 张晓云, 吕宪国, 沈松平, 等. 若尔盖高原湿地区主要生态系统服务价值评价. 湿地科学, 2008, 6(4): 466-472. [ZHANG X Y, LYU X G, SHEN S P, et al. Service value evaluation of main ecosystems of Ruoergai Plateau Marshes. Wetland Science, 2008, 6(4): 466-472.]

[20] 庞丙亮, 崔丽娟, 马牧源. 若尔盖高寒湿地生态系统服务价值评价. 湿地科学, 2014, 12(3): 273-278. [PANG B L, CUI L J, MA M Y, et al. Evaluation of ecosystem services valuation of alpine wetlands in Zoigê Plateau. Wetland Science, 2014, 12(3): 273-278.]

\title{
Improvement and application of the multi-destination travel cost sharing model in recreation value evaluation of Zoige county
}

\author{
DENG Mao-tao ${ }^{1}$, SHANG Min ${ }^{1}$, YANG Zhi-juan ${ }^{1}$, YANG Miao², \\ YANG Zheng-xing ${ }^{1}$, HE Si-miao' \\ (1. Sichuan Aba Ecology and Environmental Monitoring Centre, Aba 624000, Sichuan, China; \\ 2. Sichuan Academy of Environmental Sciences, Chengdu 610041, China)
}

\begin{abstract}
Multi-destination round-trip travel is a hot spot in the evaluation of tourism value with the travel cost method (TCM). But it is a key problem in the evaluation of recreation value to divide the public cost of multi-destination travel and determine the cost weight of each destination objectively and accurately. Therefore, this paper, with Zoige county as object of study, and most popular Huahu Lake and the First Bend of Yellow River in Zoige county as two sample points, introduces the concepts of public travel costs and the direct costs of destination, to improve the calculation model of public cost sharing in multi-destination travel; that is, the ratio of direct expenses in the destination to be evaluated to the total direct expenses of multi-destination is taken as the shared weight of the destination to be evaluated in the public travel expenses. The calculation model shares the public cost of the trip according to tourists' own consumption characteristics surveyed, and tries to avoid the influence of subjective assumptions, and to make the sharing of expenses more objective and reasonable. This can properly solve the widespread multi-destination round-trip travel problem. Based on the interval travel cost method, this paper applies the improved cost sharing calculation model to evaluate the recreation value of Zoige county. In 2017, the recreation value was 3.109 billion yuan and the per capita recreation value was 1538 yuan, in which, the travel cost was 2.506 billion yuan, the per capita travel cost was 1240 yuan, the consumer surplus was 0.603 billion yuan, and the per capita consumer surplus was 298 yuan. This paper can help to improve recreation value assessment methods by modifying the multi-destination travel cost sharing model. The research results can provide scientific guidance for the development and planning of eco-tourism industry in Zoige county.
\end{abstract}

Keywords: recreation value; travel cost method; multi-destination travel; cost sharing model; Zoige county 